\title{
Co-circulation of Peste-des-Petits-Ruminants Virus Asian lineage IV with Lineage II in Nigeria
}

T. Y. Woma ${ }^{1,2,}{ }^{*}$, A. M. M. Qasim ${ }^{2}$, A. A. Sabi ${ }^{2}$, M. N. Abraham², O. D. Olaiya ${ }^{2}$, D. Bailey ${ }^{3}$, D. Shamaki ${ }^{2}$ and M. Quan ${ }^{1}$.

${ }^{1}$ Department of Veterinary Tropical Diseases, University of Pretoria, Private Bag X04 Onderstepoort 0110, South Africa.

${ }^{2}$ Morbilliviruses Research Laboratory, National Veterinary Research Institute, P.M.B 01 Vom 930001, Nigeria

${ }^{3}$ School of Immunity and Infection, University of Birmingham, B15 $2 \pi$, Birmingham, U.K

*Corresponding author: melvyn.quan@up.ac.za; Tel: +27 125298142

Ethical statement: The project was performed under the approval of the Animal Ethics Committee of the University of Pretoria (V082-11).

\section{Summary}

Peste-des-petits-ruminants (PPR), a major small ruminant transboundary animal disease, is endemic in Nigeria. Strains of the causal agent, peste-des-petits-ruminants virus (PPRV), have been differentiated into four genetically distinct lineages based on the partial sequence of the virus nucleoprotein (N) or fusion (F) genes. PPRV strains that were identified initially in Africa were grouped into lineages I, II and III and viruses from Asia were classified as lineage IV and referred to as the Asian lineage. Many recent reports indicate that the Asian lineage is now also present in Africa. With this in mind, this study was conducted to re-assess the epidemiology of PPRV in Nigeria. A total of 140 clinical samples from 16 sheep and 63 goats with symptoms suggestive of PPR were collected from different states of Nigeria during a four year period (2010-2013). They were analyzed by the amplification of fragments of the $\mathrm{N}$ gene. Results for $33(42 \%)$ animals were positive. The phylogenetic analysis of the $\mathrm{N}$ gene sequences with those available in GenBank showed that viruses that were detected belong to both lineage II and IV. Based on an analysis of the $\mathrm{N}$ gene sequences, the lineage IV isolates grouped into two clades, one being predominant in 
the north-eastern part of the country and the other found primarily in the southern regions of the country. This study reports the presence of PPRV Asian lineage IV in Nigeria for the first time.

KEYWORDS: Morbillivirus, PPR, West Africa, viral spread, nucleoprotein, sheep.

\section{Introduction}

Peste-des-petits-ruminants (PPR) is a serious infectious disease of sheep and goats. It is endemic in large parts of Africa (from North Africa to Tanzania), the Middle East, Turkey, Iran and many countries in Asia (Libeau et al., 2014). The disease is characterized by pyrexia, depression, anorexia, diarrhoea, respiratory distress, mucopurulent oculo-nasal discharges with matting of the eyelids, necrotic oral lesions with a fetid smell and sometimes abortion in pregnant animals. In Nigeria most outbreaks occur between February and May, the dry harmattan season and also between July and September, mostly in the south-eastern and south-western parts of the country.

This disease is caused by peste-des-petits-ruminants virus (PPRV), which belongs to the genus Morbillivirus within the family Paramyxoviridae, along with rinderpest virus, measles virus, canine distemper virus, cetacean morbillivirus virus and phocine distemper virus (King et al., 2012). They are enveloped viruses with a genome composed of a non-segmented single-stranded negative sense RNA. The genome of PPRV is 15948 nucleotides in size and encodes for two non-structural proteins $\mathrm{C}$ and $\mathrm{V}$, and six structural proteins arranged in the order: nucleoprotein $(\mathrm{N})$, phosphoprotein $(P)$, matrix protein $(M)$, fusion protein $(F)$, hemagglutinin protein $(H)$ and viral RNA-dependent polymerase (L) (Diallo, 2003; Bailey et al., 2005; Truong et al., 2014). Based on partial sequences of the $\mathrm{N}$ and F genes, PPRV has been classified into four genetically distinct lineages (I, II, III and IV) even though the virus is serologically monotypic (Banyard et al., 2010; Kwiatek et al., 2011). Viruses that were first identified in Africa belong to lineages I, II and III while viruses belonging to lineage IV, also referred to as the Asian lineage, have been isolated in many Asian countries including Iran, Turkey and the Middle East (Banyard et al., 2010; Kwiatek et al., 2011). However, over the last one to two decades, there have been reports of the presence of the 
Asian lineage of PPRV in African countries such as Sudan, Morocco, Egypt, Algeria, Uganda, Gabon, Cameroon and Central African Republic (Banyard et al., 2010., Kwiatek et al., 2011., Sharawi and Abd-El-Rahim, 2011., De Nardi et al., 2012., Luka et al., 2012., Maganga et al., 2013).

PPRV identified in Nigeria from the 1970s up until 2000 all belonged to lineage II (Shamaki, 2002., Kwiatek et al., 2007., Banyard et al., 2010 ). However, following reports of the circulation of lineage IV in Cameroon and the Central African Republic, it has become necessary to re-assess the epidemiological situation of PPRV in Nigeria especially in states at the border with neighbouring countries. Indeed, Cameroon has a long porous border with Nigeria and many inhabitants of north-eastern Nigeria (Taraba, Adamawa, Borno States) have families in that country, thus facilitating animal trade and smuggling and the taking advantage of the limited control over animal movements at the border.

\section{Materials and methods}

\section{Samples}

A total of 140 clinical samples consisting of spleen, trachea, lung, liver and lymph nodes were collected between 2010 to 2013 from 16 sheep and 63 goats with symptoms suggestive of PPRV infection. These animals were from different states representing the six different agro-ecological zones of Nigeria. Samples were transported on ice to the laboratory at the National Veterinary Institute in Vom. The location of each sampling was recorded using the GPSMAP ${ }^{\circledR} 76$ versatile navigator (Garmin).

\section{RNA extraction and RT-PCR}

A $10 \% \mathrm{w} / \mathrm{v}$ homogenate was made by grinding tissue with sterile glass in DMEM medium and the suspension was then clarified at $1200 \times \mathrm{g}$ for $5 \mathrm{~min}$. Total RNA was extracted from the sample supernatant using a Qiagen RNeasy Plus RNA extraction kit (Qiagen, Germany) according to the manufacturers' instructions. Reverse transcription PCR (RT-PCR) was performed with $2 \mu \mathrm{l}$ 
extracted RNA using the Qiagen ${ }^{\circledR}$ one step RT-PCR kit (Qiagen, Germany) to amplify a 351 bp segment of the PPRV N gene with the NP3/NP4 diagnostic primers (Couacy-Hymann et al., 2002). PCR products were resolved on a $1.2 \%$ agarose gel stained with ethidium bromide to reveal the expected band size.

\section{Sequencing and phylogenetic analysis}

Amplified products were purified for sequencing using the Wizard ${ }^{\circledR}$ SV gel and PCR clean-up system (Promega ${ }^{\circledR}$, USA) according to the manufacturer's instructions. The purified DNA was quantified by spectrophotometer (NanoDrop ${ }^{\circledR}$ ND-1000, PeQlab Biotech Gmbh). Sequencing was carried out in both forward and reverse directions by Inqaba Biotech (South Africa).

The nucleotide sequences of the $\mathrm{N}$ gene amplicons were aligned using the Molecular Evolutionary Genetics Analyses (MEGA) software version 5 (Tamura et al., 2011). Phylogenetic trees were constructed by comparisons with unique published sequences available (i.e. in peer review journals) in GenBank. A TIM+G substitution model was determined by Modeltest v3.7 (Posada and Crandall, 1998) for the $\mathrm{N}$ gene. Distance (neighbour-joining) and character (Bayesian, maximum parsimony) based phylogenies of the nucleotide sequences were explored using PAUP* 4.0b10 (Farris et al., 1994) and Mr Bayes v3.2.2 (Ronquist and Huelsenbeck 2003). The reliability of each tree was estimated using 1,000 bootstrap replicates and the percentage of replicate trees in which the associated taxa clustered together in the bootstrap test are shown next to the branches (Felsenstein, 1985). Sequences have been submitted to GenBank under accession numbers KF479408 - KF479444, KJ124726 - KJ124773.

\section{Results and Discussion}

During this study, most of the outbreaks of PPR occurred during February to May, which is part of the dry harmattan season, in northern states and July to September, part of the rainy season, in southern states. Most of the affected animals were between 3 and 12 months of age. More goats 
than sheep were affected in areas where they grazed together and shared the same drinking sources.

A total of 140 samples from 79 animals were tested by RT-PCR. Samples for 33 animals were positive, i.e. 2 out of 16 sheep (13\%) and 31 out of 63 goats (49\%). The details of the positive samples are summarized in Table 1 . The amplified products were sequenced and the data were analysed together with PPRV N gene sequences available in GenBank (Kwiatek et al., 2007, 2011; Banyard et al., 2010). Three phylogenetic analysis methods were used, which all generated trees with similar topologies. The phylogeny inferred with the distance methods was consistent with those of the character based analysis. Based on the partial N gene sequence, most of the PPRV strains collected in Nigeria between 2010 and $2013(n=26)$ grouped together in lineage IV and only a few grouped in lineage II $(n=7)$ (Fig. 1). Lineage IV isolates from Nigeria were subdivided into two clades (i.e. IV-NigA and IV-NigB), supported by a bootstrap value of $90 \%$. Samples from the two positive sheep belonged to IV-NigA. All samples in IV-NigA were collected between February and April 2012 and February 2013. PPRVs lineage IV-NigA were distributed across the entire north-eastern part of the country and present only in one southern state (Ondo) (Fig. 2). PPRVs lineage IV-NigB were present only in the north-east of the country, in Plateau and Adamawa states (Fig. 2). The majority of the lineage IV-NigB viruses occurred in the three southern states of Cross River, Imo and Anambra and were isolated from goat samples collected in April 2010, September 2011, July 2012 and March 2013. Lineage IV-NigB viruses showed 94 \% identity with IV-NigA and were related most closely to viruses identified in Cameroon and Sudan in 1997 and 2008, respectively. 


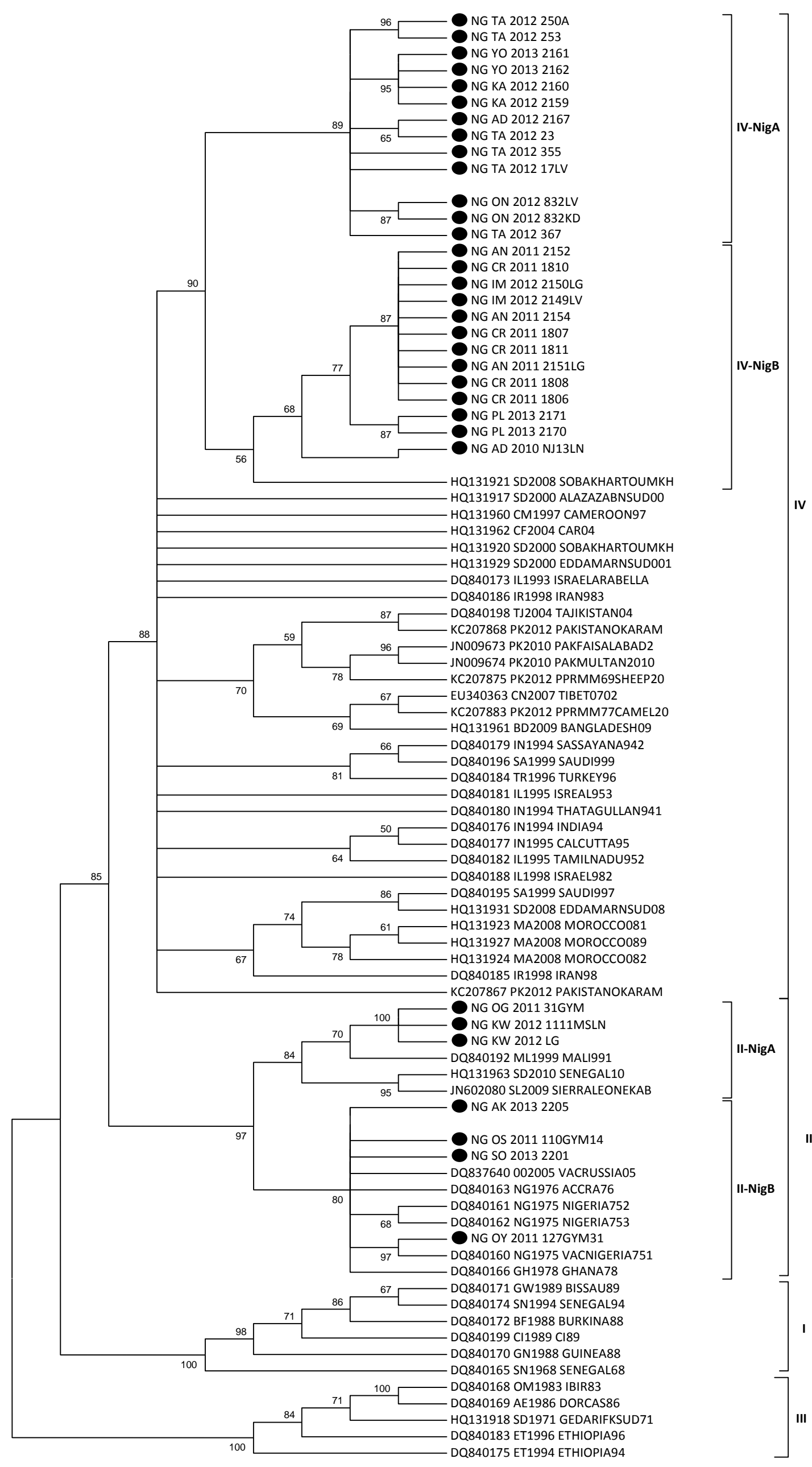

Fig. 1: PPRV N gene phylogenetic analysis. Neighbour-joining unrooted cladogram showing the relationship between the $\mathrm{N}$ gene sequences from this study (indicated by black circles, ISO 3166 country code and state code, year of sample collection and sample laboratory number) with unique published sequences obtain fd from GenBank (indicated by accession number, ISO 3166 country code, year of isolation and name of isolate). The numbers at the nodes are bootstrap values obtained from 1000 re-samplings. 


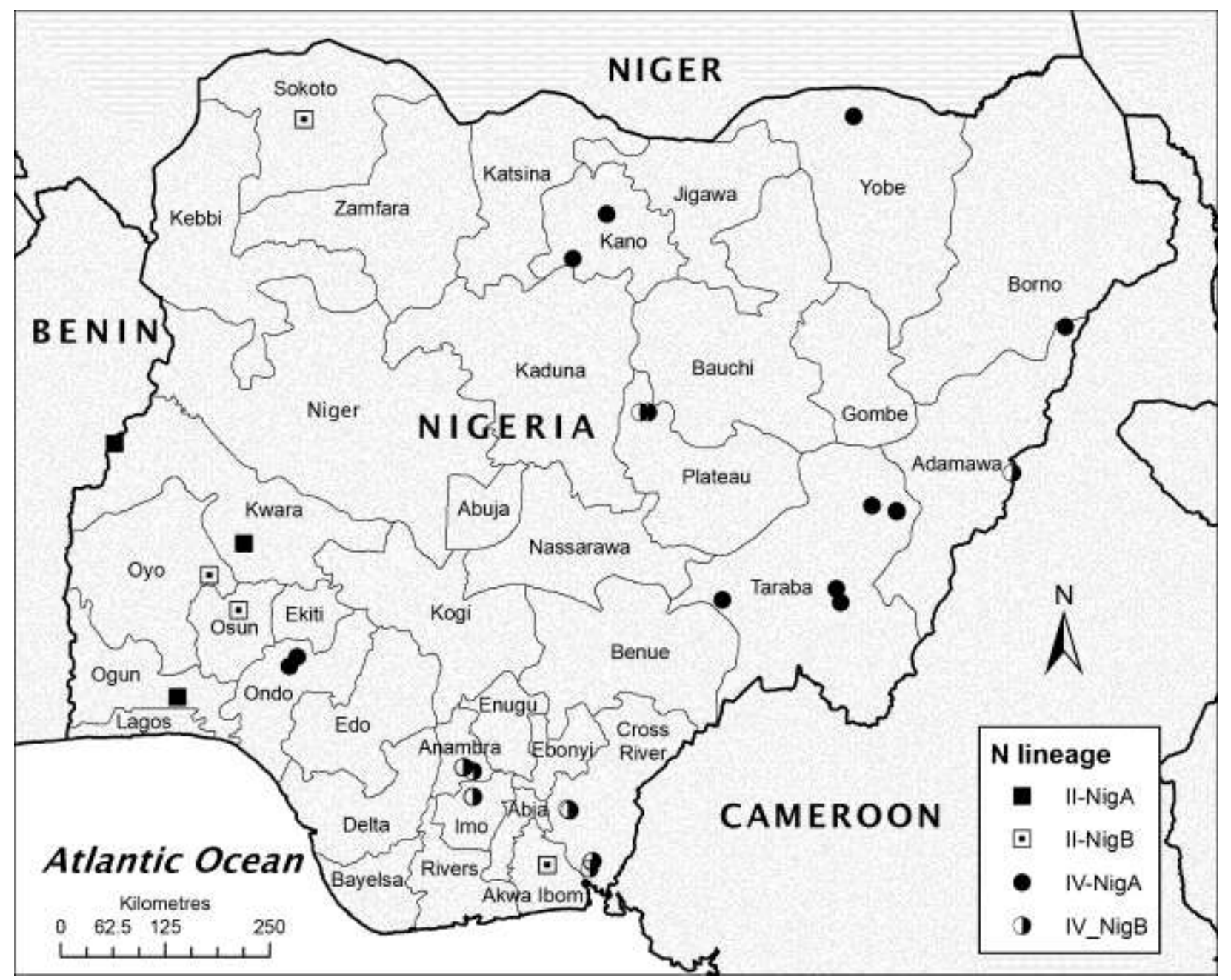

Fig. 2: The distribution of PPRV lineage II (circles) and IV (squares) in different states of Nigeria. The map shows the location of villages where positive PPR samples were collected (see Table 1).

Only seven lineage II virus sequences from the present study were similar to earlier isolates from Nigeria collected in the 1970s and 1990s (Kwiatek et al., 2007; D. Shamaki, 2002). They were collected from goats in September 2011, May 2012 and May 2013. The lineage II sequences from this study also formed two separate clades, II-NigA and II-NigB (Fig. 1). Lineage II-NigA samples had a high identity with PPRV strains identified in Mali obtained in 1999 (DQ840198), while those in lineage II-NigB showed 98 \% identity with the Nigerian 1975/1 virus (DQ840160) that has been attenuated and is commonly used as a vaccine (Diallo et al., 1989; Kwiatek et al., 2007). 
Table 1. Details of animals in Nigeria positive for PPRV by RT-PCR.

\begin{tabular}{|c|c|c|c|c|c|c|c|c|c|}
\hline State & Location & Species & Breed & Age* & Anamnesis & $\begin{array}{l}\text { Collection } \\
\text { date }\end{array}$ & $\begin{array}{l}\text { Sample } \\
\text { type }\end{array}$ & Sample name & $\begin{array}{l}\text { Sub- } \\
\text { Clade }\end{array}$ \\
\hline Adamawa & Njobli & $\mathrm{Ca}$ & WAD & 7 & $\begin{array}{l}\text { Diarrhoea, matted eyelids, oral lesions, } \\
\text { nasal discharges, anorexia }\end{array}$ & 12.04 .2010 & Lung & $\begin{array}{l}\text { NGAD2010- } \\
\text { NJ13LN }\end{array}$ & IV-NigB \\
\hline Anambra & Adazi-Ani & $\mathrm{Ca}$ & WAD & 6 & $\begin{array}{l}\text { Cough, fever, anorexia, raised hair coat, } \\
\text { diarrhoea }\end{array}$ & 21.09.2011 & Lung & $\begin{array}{l}\text { NGAN2011- } \\
\text { 2151LG }\end{array}$ & IV-NigB \\
\hline $\begin{array}{l}\text { Cross } \\
\text { River }\end{array}$ & Akpet Central & $\mathrm{Ca}$ & WAD & 4 & $\begin{array}{l}\text { Oculo-nasal discharges, oral lesions, } \\
\text { diarrhoea }\end{array}$ & 23.09.2011 & Liver & NGCR2011-1807 & IV-NigB \\
\hline $\begin{array}{l}\text { Cross } \\
\text { River }\end{array}$ & Ikot-Omin & $\mathrm{Ca}$ & WAD & 4 & $\begin{array}{l}\text { Oculo-nasal discharges, oral lesions, } \\
\text { diarrhoea }\end{array}$ & 23.09.2011 & Liver & NGCR2011-1806 & IV-NigB \\
\hline $\begin{array}{l}\text { Cross } \\
\text { River }\end{array}$ & Mariam & $\mathrm{Ca}$ & WAD & 4 & $\begin{array}{l}\text { Oculo-nasal discharges, oral lesions, } \\
\text { diarrhoea }\end{array}$ & 23.09.2011 & Liver & NGCR2011-1808 & IV-NigB \\
\hline $\begin{array}{l}\text { Cross } \\
\text { River }\end{array}$ & Biase & $\mathrm{Ca}$ & WAD & 4 & $\begin{array}{l}\text { Oculo-nasal discharges, oral lesions, } \\
\text { diarrhoea }\end{array}$ & 23.09 .2011 & Liver & NGCR2011-1810 & IV-NigB \\
\hline $\begin{array}{l}\text { Cross } \\
\text { River }\end{array}$ & Ikot-Eneobong & $\mathrm{Ca}$ & WAD & 4 & $\begin{array}{l}\text { Oculo-nasal discharges, oral lesions, } \\
\text { diarrhoea }\end{array}$ & 23.09.2011 & Liver & NGCR2011-1811 & IV-NigB \\
\hline Anambra & Umuchi & $\mathrm{Ca}$ & WAD & 7 & $\begin{array}{l}\text { Cough, fever, anorexia, raised hair coat, } \\
\text { diarrhoea }\end{array}$ & 23.09.2011 & $\begin{array}{l}\text { Lymph } \\
\text { node }\end{array}$ & NGAN2011-2154 & IV-NigB \\
\hline Anambra & Amada & $\mathrm{Ca}$ & WAD & 5 & $\begin{array}{l}\text { Oculo-nasal discharges, oral lesions, } \\
\text { diarrhoea }\end{array}$ & 22.09 .2011 & Liver & NGAN2011-2152 & IV-NigB \\
\hline Osun & Iregba & $\mathrm{Ca}$ & WAD & 4 & $\begin{array}{l}\text { Blood tinged diarrhoea, pneumonia, } \\
\text { vesicular stomatitis }\end{array}$ & 11.09.2011 & Lung & $\begin{array}{l}\text { NGOS2011- } \\
\text { 110GYM14 }\end{array}$ & II-NigB \\
\hline Ogun & ljebu-Ode & $\mathrm{Ca}$ & WAD & 9 & Oral lesions, diarrhoea, cough, & 29.09.2011 & Lung & $\begin{array}{l}\text { NGOG2011- } \\
\text { 31GYM }\end{array}$ & II-NigA \\
\hline Oуо & Bodija & $\mathrm{Ca}$ & WAD & 11 & $\begin{array}{l}\text { Soiled hindquarters, oral lesions with } \\
\text { putrid smell, anorexia, sneezing }\end{array}$ & 29.09.2011 & Kidney & $\begin{array}{l}\text { NGOY2011- } \\
\text { 127GYM31 }\end{array}$ & II-NigB \\
\hline Adamawa & Gulak & $\mathrm{Ca}$ & WAD & 6 & Raised hair coat, depression, diarrhoea & 12.04.2012 & $\begin{array}{l}\text { Lymph } \\
\text { node }\end{array}$ & NGAD2012-2167 & IV-NigA \\
\hline Taraba & Kassa & Ov & WAL & 6 & $\begin{array}{l}\text { Fever, emaciated, pneumonia, anorexia, } \\
\text { diarrhoea }\end{array}$ & 27.03.2012 & Liver & NGTA2012-17LV & IV-NigA \\
\hline Taraba & Jalingo & $\mathrm{Ca}$ & WAD & 15 & Weak, depressed, fever, cough, anorexia & 01.04.2012 & Spleen & NGTA2012-367 & IV-NigA \\
\hline Taraba & Wukari & $\mathrm{Ca}$ & WAD & 11 & $\begin{array}{l}\text { Oculo-nasal discharges, oral lesions, } \\
\text { diarrhoea, fever }\end{array}$ & 30.03 .2012 & $\begin{array}{l}\text { Lymph } \\
\text { node }\end{array}$ & NGTA2013-23 & IV-NigA \\
\hline Taraba & Maihula & Ov & WAL & 5 & $\begin{array}{l}\text { emaciated, pneumonia, diarrhoea, } \\
\text { fever, matted eyelids }\end{array}$ & 17.02.2012 & Lung & NGTA2012-250A & IV-NigA \\
\hline Taraba & Garbabi & $\mathrm{Ca}$ & WAD & 6 & Matted eyelids, emaciated, pneumonia, & 31.03.2012 & Lung & NGTA2012-253 & IV-Nig \\
\hline
\end{tabular}




\begin{tabular}{|c|c|c|c|c|c|c|c|c|c|}
\hline & & & & & diarrhoea & & & & A \\
\hline Taraba & Kassa & $\mathrm{Ca}$ & WAL & 17 & Oral lesions, matted eyelids, diarrhoea & 29.03.2012 & $\begin{array}{l}\text { Lymph } \\
\text { node }\end{array}$ & NGTA2012-355 & IV-NigA \\
\hline Kano & $\begin{array}{l}\text { Kano Municipal } \\
\text { Council }\end{array}$ & $\mathrm{Ca}$ & WAL & 12 & $\begin{array}{l}\text { Pneumonia, depressed, fever, oral } \\
\text { lesions }\end{array}$ & 15.04.2012 & Lung & NGKA2012-2159 & IV-NigA \\
\hline Kano & Dogongora & $\mathrm{Ca}$ & WAL & 5 & $\begin{array}{l}\text { Anorexia, emaciated, diarrhoea, } \\
\text { weakness }\end{array}$ & 19.04.2012 & $\begin{array}{l}\text { Lymph } \\
\text { node }\end{array}$ & NGKA2012-2160 & IV-NigA \\
\hline Ondo & Akure & $\mathrm{Ca}$ & WAD & 14 & $\begin{array}{l}\text { Diarrhoea, cough, oral lesions, fever, } \\
\text { pneumonia }\end{array}$ & 27.04.2012 & Liver & $\begin{array}{l}\text { NGON2012- } \\
832 \text { LV }\end{array}$ & IV-NigA \\
\hline Ondo & Idanre & $\mathrm{Ca}$ & WAD & 7 & $\begin{array}{l}\text { Diarrhoea, cough, oral lesions, fever, } \\
\text { pneumonia }\end{array}$ & 27.04.2012 & Lung & $\begin{array}{l}\text { NGON2012- } \\
832 \text { KD }\end{array}$ & IV-NigA \\
\hline Kwara & Baruten & $\mathrm{Ca}$ & WAD & 5 & $\begin{array}{l}\text { Emaciation, diarrhoea, vesicles on feet, } \\
\text { weakness }\end{array}$ & 09.05 .2012 & $\begin{array}{l}\text { Lymph } \\
\text { node }\end{array}$ & $\begin{array}{l}\text { NGKW2012- } \\
1111 \mathrm{MSLN}\end{array}$ & II-NigA \\
\hline Kwara & Illorin & $\mathrm{Ca}$ & WAD & 5 & $\begin{array}{l}\text { Emaciation, diarrhoea, vesicles on feet, } \\
\text { weakness }\end{array}$ & 09.05 .2012 & Lung & NGKW2012-LG & II-NigA \\
\hline Imo & Eziama-Obaire & $\mathrm{Ca}$ & WAD & 13 & $\begin{array}{l}\text { Cough, fever, anorexia, raised hair coat, } \\
\text { diarrhoea }\end{array}$ & 16.07.2012 & Liver & $\begin{array}{l}\text { NGIM2012- } \\
\text { 2149LV }\end{array}$ & IV-NigB \\
\hline Imo & Iho & $\mathrm{Ca}$ & WAD & 4 & $\begin{array}{l}\text { Oculo-nasal discharges, oral lesions, } \\
\text { diarrhoea }\end{array}$ & 18.07.2012 & Lung & $\begin{array}{l}\text { NGIM2012- } \\
2150 \text { LG }\end{array}$ & IV-NigB \\
\hline Yobe & Yusufari & $\mathrm{Ca}$ & WAL & 9 & $\begin{array}{l}\text { Raised hair coat, weak, depressed, fever, } \\
\text { anorexia }\end{array}$ & 15.02 .2013 & $\begin{array}{l}\text { Lymph } \\
\text { node }\end{array}$ & NGYO2013-2161 & IV-NigA \\
\hline Yobe & Yusufari & $\mathrm{Ca}$ & WAL & 10 & $\begin{array}{l}\text { Raised hair coat, weak, depressed, fever, } \\
\text { anorexia }\end{array}$ & 15.02 .2013 & Lung & NGYO2012-2162 & IV-NigA \\
\hline Plateau & Angwa Kurma & $\mathrm{Ca}$ & WAD & 6 & $\begin{array}{l}\text { Oral lesions, diarrhoea, cough, } \\
\text { emaciation }\end{array}$ & 19.03.2013 & Lung & NGPL2013-2170 & IV-NigB \\
\hline Plateau & Jos & $\mathrm{Ca}$ & WAD & 8 & $\begin{array}{l}\text { Matted eyelids, oculo-nasal discharges, } \\
\text { depression, soiled vent }\end{array}$ & 19.03.2013 & Liver & NGPL2013-2171 & IV-NigB \\
\hline $\begin{array}{l}\text { Akwa } \\
\text { Ibom }\end{array}$ & Uyo & $\mathrm{Ca}$ & WAD & 14 & $\begin{array}{l}\text { Matted eyelids, oculo-nasal discharges, } \\
\text { depression, soiled vent, emaciated }\end{array}$ & 03.05.2013 & $\begin{array}{l}\text { Lymph } \\
\text { node }\end{array}$ & NGAK2013-2205 & II-NigB \\
\hline Sokoto & Sokoto & $\mathrm{Ca}$ & WAD & 14 & $\begin{array}{l}\text { Matted eyelids, oculo-nasal discharges, } \\
\text { depression, soiled vent, emaciated }\end{array}$ & 21.05 .2013 & $\begin{array}{l}\text { Lymph } \\
\text { node }\end{array}$ & NGSO2013-2201 & II-NigB \\
\hline
\end{tabular}

* Age in months, Ca - Caprine, Ov - Ovine, WAD - West African Dwarf, WAL - West African Long-leg. 
The findings of this study relating to PPR surveillance in Nigeria over a four year period (2010 2013) have confirmed the widespread distribution of PPRV throughout Nigeria, as has been described since the early 1970s (Isoun and Mann, 1972) and also revealed the presence of PPRV lineage IV in the country for the first time.

Analysis of the sequence data obtained from the samples showed the presence of viruses belonging to two lineages, namely, PPRV Asian lineage IV and PPRV lineage II, the so-called "indigenous" lineage given that it is the lineage to which PPRV isolated in Nigeria between 19751976 and also in the late 1990's (Shamaki, 2002; Kwiatek et al., 2007) belong. Surprisingly, the number of samples that belonged to this "indigenous" group was small compared to those of the "emerging" lineage IV. Some earlier Nigerian samples collected between 2008 and 2009 were also classified previously as lineage IV (Diallo, A., unpublished data). The Nigerian lineage IV viruses from this study formed two distinct clades, IV-NigA and IV-NigB which were clearly distinct from other lineage IV viruses except for the sequence of a Sudanese isolate (HQ131921) (Fig. 1). Of particular interest are the samples collected in Adamawa state in April 2010. This state borders Cameroon, where a 1997 lineage IV virus (HQ131960, Fig 1) was reported (Kwiatek et al., 2011). It is tempting to think that viruses of lineage IV-NigB were first introduced into Nigeria from Cameroon and then evolved into lineage IV-NigA viruses due possibly to genetic drift following incountry transmission, as has been suggested for measles viruses (Santibanez et al., 2002; Alla et al., 2006; Waku-Kouomou et al., 2010). Further in-depth genetic analysis using next generation sequencing is planned in order to confirm this hypothesis. The presence of a lineage IV-NigA virus (NG_ON_2012_832LV) in Ondo State, a region where lineage II and lineage IV-NigB viruses are predominant may be the result of importation of infected animals from northern Nigeria. A lineage II PPRV (NG_AK_2013_2202) was identified in Akwa Ibom state in the far south of the country which is a region where lineage IV-NigB viruses predominate. This may be also as a result of importation from states bordering Benin where PPRV lineage II is predominant e.g. Ogun, Osun, Oyo and Kwara States. 
The lineage II isolates subdivided into two distinct clades. One clade was closely related to the Nigeria 75/1 vaccine strain while the second clade was closely related to viruses found in Mali, Senegal and Sierra Leone. At present, there is no information on the PPRV lineages circulating currently in Niger so the isolates collected in Yobe and Sokoto states are of particular interest. These two states have borders with Niger and while the sample collected in Sokoto (NG_SO_2013_72) was identified as belonging to lineage II-NigB the samples collected in Yobe (NG_YO_2013_2161/2162) were of lineage IV-NigB.

This study has shown that Nigerian sheep and goats are infected by viruses of two PPRV lineages: lineage II, the "indigenous lineage", which is being replaced by the Asian lineage. Kwiatek et al., (2011) reported a similar situation in Sudan where PPRV lineage IV is now dominant and has replaced lineage III that was present in the country until 2000. The authors suggested that the lineage IV viruses which were present historically in Asia and parts of the Middle East may have become more virulent and so have spread more easily to Africa. It is possible that these more virulent lineage IV PPRV strains have a selective advantage over lineage III viruses in the case of Sudan and lineage II viruses in the case of Nigeria. This view is supported by the remarkably rapid spread of the lineage IV viruses over the north-eastern part of Nigeria bordering Cameroon. It is unknown whether this change in PPRV lineage distribution in Nigeria has any relationship to pathogenicity or is just a result of geographical speciation. A more widespread analysis of PPRV in other African countries would help to understand the geographic extent of the spread of the Asian lineage within the continent.

\section{Acknowledgements}

This work was supported by a grant (RFA 2 No. 48) from the Agricultural Research Council of Nigeria through the Competitive Agricultural Research Grant Scheme (CARGS). We sincerely thank the staff of the Morbillivirus laboratory, NVRI Vom and all the field staff that helped during sample collection and other logistics. D. Shamaki is a recipient of an IAEA project on PPR. 


\section{References}

Alla, A., D. Waku-Kouomou, A. Benjouad, R. Elaouad, and T. Fabian Wild, 2006: Rapid diversification of measles virus genotypes circulating in Morocco during 2004 - 2005 epidemics. J. Med. Virol. 78, 1465-1472.

Bailey, D., A. Banyard, P. Dash, A. Ozkul, and T. Barret, 2005: Full genome sequence of peste des petits ruminants virus, a member of the Morbillivirus genus. Virus Res. 110, 119-124.

Banyard, A.C., S. Parida, C. Batten, C. Oura, O. Kwiatek, and G. Libeau, 2010: Global distribution of peste des petitis ruminants virus and prospects for improved diagnosis and control. J. Gen. Virol. 91, 2885-2897.

Couacy-Hymann, E., F. Roger, C. Hurard, J.P. Guillou, G. Libeau, and A. Diallo, 2002: Rapid and sensitive detection of peste des petits ruminants virus by a polymerase chain reaction assay. J. Virol. Methods 100, 17-25.

De Nardi, M., S.M. Lamin Saleh, C. Batten, C. Oura, A. Di Nardo, and D. Rossi, 2012: First evidence of peste des petits ruminants (PPR) virus circulation in Algeria (Sahrawi territories): outbreak investigation and virus lineage identification. Transbound. Emerg. Dis. 59, 214-222.

Diallo, A., W.P. Taylor, P.C. Lefèvre, and A. Provost, 1989: Atténuation d'une souche de virus de la peste des petits ruminants: candidat pour un vaccin homologue. Revue Elev. Méd. Vét. Pays Trop. 42 (3), 311-317.

Diallo, A., 2003: Control of PPR: classical and new generation of vaccines. Dev. Biol. 114, 85-91.

Farris, J.S., M. Kallersjo, A.G. Kluge, and C. Bult, 1994: Testing significance of incongruence. Clad. 10, 315-319.

Felsenstein J., 1985: Confidence limits on phylogenies: an approach using the bootstrap. Evol. 39, 783-791.

Forsyth, M.A., and T. Barrett, 1995: Evaluation of polymerase chain reaction for the detection and characterization of rinderpest and peste des petits ruminants viruses for epidemiological studies. Virus Res. 39, $151-163$.

Isoun, T.T., and E.D. Mann, 1972: A stomatitis and pneumoenteritis of sheep in Nigeria. Bull. Epi. Dis. Afr. 20, $167-174$. King A.M.Q., M.J. Adams, E.B. Carstens, and E.J. Lefkowitz, 2012: Virus taxonomy. Ninth report of the International Committee on the Taxonomy of Viruses. Academic Press.

Kwiatek, O., C. Minet, C. Grillet, C. Hurard, E. Carlsson, B. Karimov, E. Albina, A. Diallo, and G. Libeau, 2007: Peste des petits ruminants (PPR) outbreak in Tajikistan. J. Comp. Path. 136, 111-119.

Kwiatek, O., Y.H. Ali, I.K. Saeed, A.I. Khalafalla, O.I. Mohamed, A.A. Obeida, M.B. Abdelrahman, H.M. Osman, K.M. Taha, Z. Abbas, M. El Harrak, Y. Lhor, A. Diallo, R. Lancelot, E. Albina, and G. Libeau, 2011: Asian lineage of peste des petits ruminants virus, Africa. Emerg. Infect. Dis. 17, 1223-1231.

Libeau, G., A. Diallo, and S. Parida, 2014: Evolutionary genetics underlying the spread of peste des petits ruminants virus. Animal Frontiers 4, 14-20.

Luka, P.D., J. Erume, F.N. Mwiine, and C. Ayebazibwe, 2012: Molecular characterization of peste des petits ruminants virus from Karamoja region Uganda (2007 - 2008). Arch. Virol. 157, 29-35.

Maganga, G.D., D. Verrier, R.M. Zerbinati, C. Drosten, J.F. Drexler, and E.M. Leroy, 2013: Molecular typing of PPRV strains detected during an outbreak in sheep and goats in south-eastern Gabon in 2011. Virol. J. 10, 82-86.

Posada, D., and K.A. Crandall, 1998: MODELTEST: testing the model of DNA substitution. Bioinformatics 14, $817-818$. 
Ronquist, F., and B. Huelsenbeck, 2003: MrBayes 3: Bayesian phylogenetic inference under mixed models.

Bioinformatics 19, 1572-1574.

Saitou, N., and M. Nei, 1987: The neighbor-joining method: A new method for reconstructing phylogenetic trees. Mol. Biol. Evol. 4, 406-425.

Santibanez, S., A. Tischer, H. Alla, A. Siedler, and H. Hengel, 2002: Rapid replacement of endemic measles virus genotypes. J. Gen. Virol. 83, 2699-2708.

Shamaki, D., 2002: Some aspects of serological and molecular epidemiology of peste des petits ruminants (PPR) in Nigeria. PhD Thesis, University of Ibadan, Ibadan, Nigeria.

Sharawi, S.S.A., and I.H.A. Abd-El-Rahim, 2011: Nucleotide sequencing and phylogenetic analysis of fusion epitope for Egyptian peste des petits ruminants virus (PPRV) predicting unique criteria stated as Egypt 2009. Inter. J. Virol. 7, 204209.

Tamura, K., M. Nei, S. Kumar, 2004: Prospects for inferring very large phylogenies by using the neighbor-joining method. Proc. Natl. Acad. Sci. (USA) 101, 11030-11035.

Tamura, K., D. Peterson, N. Peterson, G. Stecher, M. Nei, and S. Kumar, 2011: MEGA5: Molecular evolutionary genetics analysis using maximum likelihood, evolutionary distance, and maximum parsimony methods. Mol. Biol. Evol. 28, 2731-2739.

Truong, T., H. Boshra, C. Embury-Hyatt, C. Nfon, V. Gerdts, S. Tikoo, L.A. Babiuk, P. Kara, T. Chetty, A. Mather, and D.B. Wallace, 2014: Peste des petits ruminants virus tissue tropism and pathogenesis in sheep and goats following experimental infection. PLoS One 9, 1-13.

Waku-Kouomou, D., F. Freymuth, I. Parent Du Châtelet, T. Fabian Wild, and B. Horvat, 2010: Co-circulation of multiple measles virus genotypes during an epidemic in France in 2008. J. Med. Virol. 82, 1033-1043. 